\title{
Perspectives on climate change and adaptation funding in developing countries
}

\author{
PLALTHAPERSAD-PILLAY AND AG OOSTHUIZEN ${ }^{1}$
}

\begin{abstract}
Most studies concur that climate change could seriously affect the sustainability and well-being of developing countries as they depend directly on climate-sensitive natural resources for their livelihood endeavours. This could primarily occur through reduced agricultural productivity, a higher incidence of diseases, the displacement of people, loss of livelihood and food price increases, all of which could contribute to food insecurity, malnourishment and escalating poverty. Although developing countries have contributed the least to Green house Gas (GHG) emissions, they stand to lose the most and it is likely that many of the development gains that have been made thus far will be reversed. To ensure that poverty reduction and economic growth do not become elusive goals for developing countries, it will be necessary to provide funds for potential adaptation measures to prevent these countries slipping further down the Human Development Index (HDI) ranking. In this paper, we will use Africa as a reference and look at the funds required for adaptation, the possible sources of funds and the conflict that may occur in prioritizing development objectives.
\end{abstract}

Keywords: Climate change, sustainability, Greenhouse Gas (GHG) emissions, porverty reduction, Human Development Index (HDI)

Disciplines: Economics, Environmental Studies, Sustainability Studies, African Studies.

\section{Introduction}

The Intergovernmental Panel on Climate Change (IPPC 2007) predicts that even under a modest temperature rise of $1-2.5^{\circ} \mathrm{C}$, a host of eventualities such as diminished crop yields, a higher risk of hunger, greater exposure to malaria, extinction of almost 20-30 per cent of all plant and animal species, and a greater proportion of people facing water stress would be exacerbated. Floods, droughts and tropical cyclones are predicted to increase in frequency, threatening livelihoods and making them more fragile. Sea level rise is a significant risk to

1. Prof. P Lalthapersad-Pillay and Prof. AG Oosthuizen are members of staff in the Department of Economics, University of South Africa. Contact details: P Lalthapersad-Pillay: (lalthp@unisa.ac.za), and AG Oosthuizen: (tootuiz@unisa.ac.za). 
coastal communities (UNEP 2007). Developing countries are most exposed to the negative consequences of climate change perils as they have fewer resources to adapt in terms of social, technological and financial resources. Climate change could undermine the sustainable development of developing countries and their ability to meet their Millennium Development Goals (MDG) targets (UNFCCC 2007). In this paper, we start by highlighting the ramifications of climate change for developing countries and the African continent in particular. This is followed by a discussion of adaptation and estimates of the funding required for adaptation. An analysis of some of the shortcomings in funding arrangements and policy recommendations are also briefly touched on.

\section{Climate change in the context of developing countries}

The $4^{\text {th }}$ Assessment Report of the IPCC (2007) has reaffirmed many realities about climate change. There is general agreement that warming of the climate system is a certainty and that global warming stems directly from man-made emissions of greenhouse gases (mostly $\mathrm{CO}_{2}$ ). The atmospheric levels of carbon dioxide rose from a pre-industrial value of 278 parts per million o 379 parts per million in 2005 and the average global temperature rose by $0.74^{\circ} \mathrm{C}$. This level is deemed as both the "largest and fastest warming trend in the history of the Earth (UNFCCC 2007:8). A greater part of the warming occurred in the last 25 years. Despite efforts to slowdown greenhouse gas emissions, the Earth will continue warm (UNFCCC 2007). The consequences of global warming may not be confined to a few isolated effects. Global warming could affect the type, the incidence and magnitude of extreme events such as tropical cyclones, floods, droughts and heavy precipitation events which are possible even with small increases in temperature (Meehl et al. 2007).

Although the impact of climate change will have serious implications for all countries, it is the developing countries that will bear the greatest brunt given that they rely primarily on natural resources for their economic activity (AU Commission et al. 2010). Developing countries are not a homogenous group as each one has a unique set of circumstances and the impact of climate change at a country-specific level will depend on the climate it experiences, its geographical location and its social, economic and political contexts. Therefore, countries' adaptation strategies will be largely determined by its specific circumstances. But there are some commonalities that apply to all countries and regions although in different degrees. The key sectors that will be affected are agriculture, water resources, human health, ecosystems, biodiversity and coastal zones (UNFCCC 2007). Climate change is likely to affect the natural resource base, livelihood patterns, income generation and the sustainability of the wider economy in developing countries. Developing countries' vulnerability stems from a host of factors such as low economic growth rates, high levels of poverty, low levels of education, subdued health status, and an absence of financial, institutional and human resources to adapt to the adversities that climate change will pose (AU Commission et al. 2010). It is most possible that developing countries in future may have to content with food and water shortage, and an outbreak of diseases that may prove to be catastrophic to billions of people (UNFCCC 2007). At a macro level climate change in developing countries threatens to restrict economic growth and slowdown development initiatives, which will push large numbers of people into poverty due to the loss of livelihood (UNECA 2010). Worse still it could weaken the ability of developing countries to meet their MDG targets, which may indirectly imply the loss of many previously attained development gains (UNDP 2006) 
The fact that developing countries would find their development endeavours offset by the effects of climate change makes it crucial that international assistance and support for countries' national planning efforts, capacity-building ventures and the provision of technology and funding are put in place. With regard to adaptation, the UNFCCC (2007) has urged that adaptation serve the dual purposes of meeting the needs of developing countries and allaying fears. The UNFCCC (2007) warns that the pace at which climate change is likely to unfold means that it is vital that the vulnerability of developing countries to climate change is contained and their capacity to adapt bolstered and national adaptation plans is put into practice. The vulnerability that developing countries are likely to experience in future is not only tied to climate change but also to the development strategies they adopt. This makes it crucial that adaptation be handled in the context of national and global development endeavours.

\subsection{The impact on Africa}

Whilst climate change and climate variability will most likely be consequential for all countries, African countries could experience its reverberations even though they are least responsible for the problem. Although Africa is responsible for less than 4 per cent of Green House $\mathrm{Gas}(\mathrm{GHG})$ emissions, climate adversities such as higher temperatures, variations in rainfall patterns, rising sea levels, floods, and droughts are expected to become the norm (UNECA 2010; Few et al. 2004; Christensen et al. 2007). It is predicted that climate change may precipitate a great number of climatic shocks and disasters which may reduce agricultural output and diminish food security in African countries (AU Commission et al. 2010; Boko et al. 2007). Africa's vulnerability to climate change is confounded on many fronts, that is, its dependency on natural resources, its geographical position, its current health and socioeconomic status, plus its shortages of resources on the financial, institutional and labour fronts. It is argued that these realities could undermine Africa's ability to initiate adaptation strategies (UNECA 2010). Harmful climate change effects in concert with other human actions will heighten Africa's exposure given its low ability to adapt (AU Commission, et al. 2010).

Climate-change will impact greatest on the poor as they are least resilient and their livelihood is tied to climate-sensitive resources such as agriculture, fisheries, forestry and other natural resources (UNECA 2010; Christensen et al. 2007; FAO 2003). Furthermore, their places of settlement are most likely to be affected by climate extremes, thus compromising their fragile existence, causing a loss of assets, savings and bringing hardship and suffering.

Africa's vulnerability to climate change is evident in the climate stresses that many parts of Africa are currently undergoing. Many areas in Africa are deemed to have climates that have been dubbed as the most variable in the world when viewed over seasonal spans or over decades. Africa's erratic climate is evidenced by flood and drought activity that occur in the same area within months of each other. It is estimated that at least one-third of African people already live in drought-prone areas and 220 million people are exposed to drought each year (UNFCCC 2007).

The joint presence of other situational factors together with current climatic variability is likely to compound Africa's ability to cope with climate change. Current development backlogs that beset these countries are responsible for their negligible adaptive ability 


\section{(UNFCCC 2007)}

The $3^{\text {rd }}$ Assessment Report of the IPCC highlighted a number of negative effects stemming from climate change pertaining to low grain yields, water runoff and water availability in the Mediterranean and southern African countries, becoming urgent issues, increased drought activity and certain plant and animal species becoming extinct. All these factors have a direct bearing on livelihoods and are more acute due to a low adaptive capacity (IPCC 2007). In the $4^{\text {th }}$ Assessment Report of the IPCC, the combination of climate change and other factors that drive change in Africa are acknowledged as being "multiple stresses" that increase vulnerability to climate change (IPCC 2007).

The predictions for temperature for Africa are that the entire continent is likely to experience higher warming on season-wide basis. Even the drier subtropical regions are likely to get warmer (UNFCCC 2007). In its $4^{\text {th }}$ Assessment Report, the IPCC raised seven areas of concern specific to the African continent:

1. Africa is especially prone to the adversity posed by climate change and its situation is worsened by the presence of "multiple stresses" and a diminished ability to adapt (IPCC 2007). The economic base of many African economies is climate-sensitive ecological resources, for example, fisheries, agriculture, forestry, other natural resources and tourism (UNECA 2010). Thus, the economic effects from climate change could be large. This situation is complicated by other factors such as poor economic growth rates, high levels of poverty, financial and institutional shortcomings, inadequate human resources, capacity constraints, degradation of the ecosystem, internal strife and conflict. These are some of the factors that are responsible for the current weak adaptive capacity in Africa (IPCC 2007).

2. Despite adaptation measures being implemented in farming communities in some African countries, the long term viability and protection against future climate events of these communities has been questioned (IPCC 2007).

3. In most African countries agricultural output and food security (and even access to food) could suffer enormously from climate variability. Agricultural production could be negatively affected by the loss of land, reduced growing seasons, and uncertainty in cultivation practices in terms of what to plant and when to plant (UNFCCC 2007). Agriculture in Africa contributes approximately 50 percent of a country's total exports and 21 per cent of its Gross Domestic Product (GDP). The proportion of the land that can be used for rain-fed and crop production is also expected to fall by 2080 . Tied to this is the number of undernourished people that is projected to rise by about 50 million in the absence of any policy interventions (UNECA 2010). Those African countries that are currently saddled with semi-arid conditions will find that achieving the necessary agricultural output will become even more difficult. It is projected that by 2080 the proportion of semi-arid land in Africa could rise by 5-8 per cent. It is possible that production in so-called marginal lands could be eliminated all together. In terms of precipitation, lower annual rainfall in large parts of Mediterranean Africa and northern Sahara is expected. Southern Africa, especially the winter rainfall region and western parts could also experience lower levels of rainfall (UNFCCC 2007). The revenue from the sale of crops is predicted to fall by almost 90 per cent in 2020, a situation that will be borne mainly by small-scale farmers. Yields from rain-fed agriculture are projected to fall by 50 per cent in many African countries. This situation would contribute to the worsening food security in the African region (IPCC 2007; Fischer et al. 2002). 
4. Climate change could exacerbate water stress that some countries currently endure, while other unaffected countries could find themselves exposed to increasing water stress. The availability of water, access to water and demand for water are likely to be affected by climate change. About 25 per cent of Africa's population (200 million) presently have to cope with water stress (IPCC 2007; Ashton 2002). Climate change is expected to expose almost 250 million people in Africa to increased water stress by 2020 and the figure is likely to rise sharply to between 250 - 600 million by the 2050s, primarily in North and Southern Africa (UNECA 2010; De Wit \& Jacek 2006). This water stress will have feedback effects on agriculture and industrialization. Flood and drought activity will become both more recurrent and severe. It is projected that by 2080, North Africa, West Africa and Southern Africa will be three of the world's five regions that will be most at risk of flooding (IPCC 2007). Reduced volumes of water to hydropower dams and the scarcity of biomass energy will impact on the availability of energy and have a negative effect on industrialization in Africa. Climate change will not only thwart socio-economic well-being, it will have profound repercussions for human security. Climate could spark off migration and cause conflict over access to and control of water resources. Geographically, all major African rivers cross national boundaries and the likelihood of conflict over water resources is highly probable. A recent study has shown that failure to address climate change in a timely manner could increase the probability of civil conflict in Africa by 54 per cent over the next two decades (UNECA 2010).

5. Many changes in ecosystems are apparent in Southern Africa. There have been changes in grasslands and marine ecosystems. Low levels of fish stocks could be further diminished by rising water temperatures (UNFCCC 2007). There could be drying and desertification in many areas of the Sahel and southern Africa. Forest ecosystems are threatened by deforestation and forest fires even though two-thirds of the people in sub-Saharan Africa depend on forest products (UNECA 2010). Grasslands could be ruined. In terms of biodiversity, it is estimated that by 2085, certain specie habitats could be lost altogether and almost 80 to 90 per cent of these habitats could be reduced in size or be located elsewhere. Climate change could also affect tourism through its effect on ecosystems and one study argues that between $25-40$ per cent of mammal species in national parks in sub-Saharan Africa would dwindle (IPCC 2007).

6. Climate change could see low-lying areas being flooded with devastating impacts on coastal settlements. Rising sea levels will damage mangroves and coral reefs, wipe out infrastructure, fisheries and tourism and cause job losses. Rising sea levels could cause floods especially in the East African coastal area and make coastal cities very vulnerable in their socio-economic statures. The cost of adaptation to sea-level rise is projected to be in the region of 5-10 per cent of GDP (IPCC 2007; Sheppard 2003).

7. Climate change could add to Africa's health burden, which is the highest in the world. Malaria is the major cause of loss of human life in Africa. Climate change has been predicted to alter the ecology of some disease vectors in Africa and thereby the spread of diseases such as malaria and dengue fever (IPCC 2007; Guernier et al. 2004; WHO 2004; McMichael et al. 2004). The spread of malaria in southern Africa and East Africa could become more widespread. It is expected that 90 million more people in Africa will be at risk of contacting malaria (UNECA 2010). 


\section{Mitigation and adaptation}

The total economic burden of climate change basically consists of three elements, namely:

- The costs of mitigation (reducing the extent of climate change);

- The costs of adaptation (reducing the impact of the change); and

- The residual costs.

Residual costs are the sum of the costs of inaction, minus the benefits from both mitigation and adaptation (EEA 2007; Parry et al. 2009).

Adaptation differs from mitigation in two key respects. Firstly, it is predicted that adaptation will provide in most cases local benefits. Secondly, these benefits could be realised without long lead time (Stern 2006). Adaptation may, however, require large scale investment which is likely to be episodic and staggered and will probably only be triggered by extreme events that raise the consciousness of climate change within policymakers, hence giving legitimacy to government action (Adger et al. 2005). This may be influenced by the views of scientists and economists. Many scientists view climate change as a dire and urgent threat requiring immediate large-scale action, while many economists favour a slow approach with careful cost calculations in order to avoid doing too much (Stanton \& Ackerman 2009).

This may imply that private institutions will have to start adapting on their own without the active intervention of policy. There are, however, many barriers to effective private adaptation, such as the presence of poverty, market failures, incomplete information, which makes government intervention and support critical (Stern 2006).

\section{Nature of adaptation}

Adaptation can be defined "as an adjustment in natural and human systems in response to actual or expected changes in climatic stimuli and their impacts in order to alleviate adverse impacts of changes or to exploit new opportunities" (Adger et al. 2005:77). The definition is, however, not clear-cut and in international funding circles where different criteria are applied, it makes the costs of adaptation uncertain (Parry et al. 2009).

Adaptation is considered to be the most feasible option for dealing with climate change, but in Africa, it is constrained by a limited adaptive capacity, as described above (Nkomo et al. 2006). Therefore, the adaptation process should involve both the building of adaptive capacity to increase the ability of individuals, groups and organizations to adopt changes (develop human capital), and the implementation of adaptation decisions that transform the capacity into action (Adger et al. 2005). This approach is also supported by the World Bank. In its Synthesis Report it states that the focus of adaptation strategies should be investment in human capital and the development of competent and flexible institutions to focus on weather resilience and adaptive capacity, as well as addressing the root causes of poverty. It also states that although economic development should be a central element of adaptation, it cannot be business as usual (World Bank 2010).

Some adaptations are purposeful and directed and can clearly be identified as being triggered by climate change, such as the United Kingdom Climate Impacts Programme. Adaptations can, however, also arise as a result of other non-climatic related social or economic changes, for example, when a house-owner leaves a flood-area for economic reasons (Adger et al. 2005). 
Irrespective of motivation, adaptation can generate benefits as well as costs when wider issues or longer timeframes are considered and it must be borne in mind that in some situations, adaptation to climate change may create new problems (Adger et al. 2005).

\section{Adaptation costs}

A study by Agrawala and Fankhauser (2008) found that beyond coastal protection, our knowledge of adaptation costs is still fairly limited. Adaptation costs mostly emerge from studies at country level where cost estimates form a part of a broader planning exercise. The United Nations Framework Convention on Climate Change (UNFCCC) used a series of adaptation studies for the most vulnerable countries in the world, namely the National Adaptation Programmes of Action (NAPAs) to identify and cost priority adaptations. NAPAs are, however, a poor indication of the ultimate adaptation costs as they predominantly cover preparatory measures and capacity building in agriculture and water (UNFCCC 2007).

Stern (2006) argues that adaptation to climate change will substantially raise the costs of some investments in developing countries, and that new investments in new areas may be required. This will put pressure on already scarce public resources while the attainment of the MDGs already requires international assistance.

Apart from the requirement for new adaptations, there is an adaptation deficit in developing countries - referring to the existing lack of adaptation to the current climate. Poor people and poor countries are less well-prepared to deal with current climate variability than rich people and rich countries. It is clear that low rankings in terms of development indicators (for example, per capita income, literacy and institutional capacity) are related to climate vulnerability (Noy, 2009). Most cost estimates deliberately ignore the link between development and cost of adaptation and prefer to focus on incremental adaptation over and above a baseline that supposedly includes climate-relevant development programmes (Parry et al. 2009).

The Bali Action Plan (BAP) underscored the severity of Africa's case by adding that "finance, technology development and transfer and capacity-building are crucial if Africa is to adequately adapt to climate change impacts" (UNECA 2010:13). Specifically, the Bali Plan of Action cautioned that:

- For Africa, adaptation is the main concern;

- Since Africa has contributed the least to global GHG emissions, yet is the most exposed to climate change, it must be supported in its endeavours to adapt to climate change; and

- Developed countries have committed themselves to extending financial, technological and capacity-building initiatives to developing countries given that climate change is likely to undermine sustainable development and the achievement of the MDGs.

Thus, assistance from developed countries for funding, technology and capacity-building undertakings, is a crucial component of Africa's adaptation process.

Given in Table 1 are various estimates on the cost of adaptation undertaken since 2006 which reveal a certain degree on convergence. The Parry report argues that these figures are misleading due to the fact that the studies were not independent as there was a sharing of information and that none of them have been peer-reviewed in the scientific and economic 
literature (Parry et al. 2009).

Table 1: Comparison of adaptation cost estimates in developing countries

\begin{tabular}{|l|l|l|}
\hline SOURCE & $\begin{array}{l}\text { US \$ BILLION } \\
\text { p.a. }\end{array}$ & COMMENTS \\
\hline $\begin{array}{l}\text { World Bank } \\
(2006)\end{array}$ & 9-41 (by 2015) & $\begin{array}{l}\text { Cost of climate-proofing FDI, GDI and ODA } \\
\text { flows }\end{array}$ \\
\hline $\begin{array}{l}\text { Stern Report } \\
(2006)\end{array}$ & 4-37 (at present) & $\begin{array}{l}\text { Update, with slight modification of World Bank } \\
\text { (2006) }\end{array}$ \\
\hline Oxfam (2007) & $>50$ (at present) & $\begin{array}{l}\text { Bases on World Bank, plus extrapolation of costs } \\
\text { from NAPAs and NGO projects }\end{array}$ \\
\hline UNDP (2007) & $86-109$ (by 2015) & $\begin{array}{l}\text { World Bank, plus costing of PRSP targets, better } \\
\text { disaster response }\end{array}$ \\
\hline UNFCCC (2007) & $\begin{array}{l}\text { 27-66 (by 2030) } \\
\text { Agriculture:7 } \\
\text { Water: 9 } \\
\text { Human health:5 } \\
\text { Coastal zones: } 4 \\
\text { Infrastructure: 2-41 }\end{array}$ & $\begin{array}{l}\text { The costs over and above what need to be } \\
\text { invested to renew capital stock and accommodate } \\
\text { income and population growth: also excluding } \\
\text { estimate for ecosystem adaptation }\end{array}$ \\
\hline
\end{tabular}

Source: Adapted from Parry et al. 2009.

All these studies used the same method as initially developed in 2006 by the World Bank by merely applying a 'mark-up' to the fraction of the current investment that is climate-sensitive to reflect the cost of 'climate-proofing'. A reassessment of the UNFCCC 2007 estimates for 2030 indicates that they are likely to be substantially under-estimated due to the following reasons: (i) some sectors have not been included, such as ecosystems, energy, manufacturing, retailing and tourism; (ii) some other sectors have only been partially covered; and (iii) the additional costs of adaptation have sometimes been calculated as 'climate mark-ups' against low levels of assumed investment (Parry et al. 2009).

The Parry report argues that the UNFCCC probably under-estimated investment needs for the included sectors by a factor of between 2 and 3 . If other sectors are considered it could be much more. For coastal protection the factor of under-estimation could be 2 to 3 . For infrastructure it may be several times higher. For health the 'intervention sets' that were costed relate to a disease burden that is approximately $30-50 \%$ of the anticipated total burden in low- and middle-income countries (and do not include interventions in high-income countries). By including protection of ecosystems it could add a further US $\$ 65-$ US $\$ 300$ billion per year in costs. Also, estimates are not made for mining and manufacturing, energy, the retail and financial sectors and tourism (Parry et al. 2009).

These shortcomings explain why the investment levels proposed by the UNFCCC appear so small (roughly equal to the annual cost of running two or three Olympic Games) which would require a doubling of current Official Development Assistance (ODA). According to Parry et al.( 2009), most adaptation cost estimates are, therefore, preliminary, incomplete and subject to caution due to the following gaps:

- The scope of the analysis doesn't cover all impacts and countries (implies severe underestimation of costs); 
- The depth of the analysis as all relevant adaptation options and needs for may given country and impact are not considered (may imply under -or overestimation of costs);

- The costing of measures does not include all relevant costs (may imply underestimation of costs); and

- The treatment of uncertainty and how future changes may affect costs (implication on costs also uncertain) (Parry et al. 2009).

During 2009 the World Bank upped their estimated cost of adaptation in poor countries to $\$ 75-100$ billion annually if global warming stayed at $2^{\circ} \mathrm{C}$ (Oxfam International, 2010). In its Briefing Note of 31 May 2010, Oxfam estimates that poor countries will need at least $\$ 100$ billion per year by 2020 over and above funding for existing development targets in terms of the MDGs, for adaptation. This is a significant increase from their previous estimates made in 2006.

The World Bank based its new estimates on a series of studies conducted globally and regionally. It found that the cost of developing countries to adapt between 2010 and 2050 will probably be US $\$ 70-100$ billion per year at 2005 prices. This is approximately $0.2 \%$ of the projected GDP of all developed countries or $80 \%$ of total disbursement ODA (World Bank, 2010). From an African perspective, the Chairperson of the African Union has cautioned that Africa will require the amount of $\$ 67$ billion annually to deal with adaptation (Business Green 2009).

\section{Responsibilities in terms of the funding requirements}

The literature on climate change leaves no doubt about the need for international collective action. Climate finance should, however, not be seen as aid because it is not an act of charity but an obligation under the UNFCCC (Oxfam International 2010). To meet this obligation, countries cannot use money that would otherwise have been used for health and education in poor countries. To do this it would reverse the development gains from recent years.

New funding must, therefore, be pledged. The question of who should pay is a matter of ethics: who should bear more or less responsibility for the problem and who can best afford to contribute (Stanton \& Ackerman 2009). As there is no supranational authority to provide coercive sanctions, nations will need to perceive sufficient benefits that will make them willing to participate in international treaties (Stern 2006).

During the past thirty to forty years, there have been several international treaties and responses to the threat of climate change. Stern (2006) points out that although most of these were to discuss mitigation, it also affected the funding arrangements for adaptation:

- In 1988 the IPCC was created. It issued its first report in 1990 that warned that climate change could become a pressing issue;

- At the Earth Summit in Rio de Janeiro in 1992, 189 countries (including all major developed and developing countries) ratified the United Nations Framework Convention on Climate Change (UNFCCC). It spelt out both the commitments in terms of mitigation by developed countries and the assistance pledged to developing countries;

- The Kyoto Protocol in 1997 set out the approach for binding international action with specific commitments till the 2012 being put in place; 
- The World Summit on Sustainable Development in 2002 in South Africa also addressed the issue of climate change;

- Climate change is s regular agenda item at G8 Summits. Decisions are not binding but provide strong direction to other international bodies:

- Evian Summit 2003 - statement on co-operation in science and technology

- Gleneagles 2005- Action Plan for Climate Change, Clean Energy and Sustainable Development

- St Petersburg 2006 - explored links between climate change and energy security

- The Copenhagen Accord in December which established the Copenhagen Green Climate Fund and secured a commitment from rich countries to mobilise $\$ 100$ billion a year by 2020 (Oxfam International 2010).

Unfortunately, the interaction of climate and development seems to create a paradox: economic development may accelerate climate change, which in turn could block further development, locking the world into existing patterns of inequality as the natural environment deteriorates (Stanton \& Ackerman 2009). The World Bank also refer to this issue in its 2010 report but firmly states that development is imperative as the impact of climate change will actually decrease as development takes place (World Bank 2010). The pattern and type of development should, however, not simply be business as usual. Adaptation requires a different type of development where breeding crops become more drought and flood tolerant, infrastructure is climate-proof, and so forth.

\section{(i) Funding through Development Assistance}

If adaptation is only defined in terms of climate change, it ignores the widely accepted role of development in contributing to the building of resilience. Sustainable development reduces vulnerability to climate change. Meeting the MDGs will all improve the livelihoods of vulnerable communities and, therefore, increase their ability to engage in adaptive action (Ayers \& Huq 2008). Increasing development assistance is thus essential.

\section{Figure 1: Scale of ODA and donor commitments}

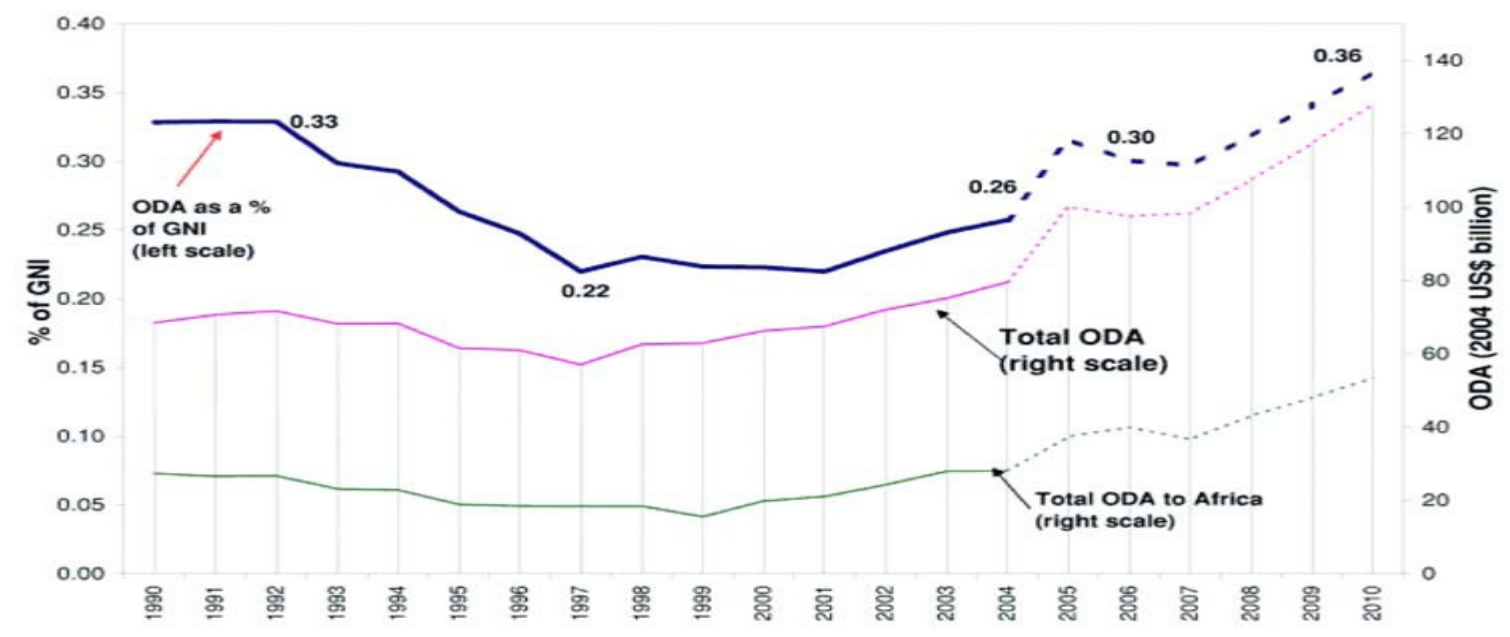

Source: OECD (2005) as cited in Stern (2006). 
Developed countries committed themselves to increase overall ODA at Monterrey in 2002. This pledge was strengthened at Gleneagles in 2005. The donor countries pledged to increase aid by US $\$ 50$ billion a year by 2010 , of which US $\$ 25$ billion was pledged for Africa. They also pledged to cancel debt worth another US $\$ 50$ billion. ODA from DAC donors alone could double by 2015 if the commitments and EU targets for $0.7 \%$ GDP in ODA are met. This is shown in Figure 1. But only five donors met the target by 2006 while five others announced timetables to meet the targets (Stern 2006). These commitments were made for development assistance in terms of meeting the MDGs, and should not be confused with the funding requirements for adaptation to climate change.

\section{(ii) International funding for adaptation}

It is difficult to separate funding for adaptation and for mitigation purposes. Funding provision that fall outside the jurisdiction of the UNFCCC's ambit is quite substantial and are targeting both adaptation and mitigation (African Partnership Forum 2006).

However, under the auspices of the UNFCCC a range of different funds have been set up to develop and integrate approaches to adaptation. It includes mainly donor contributions to the Global Environmental Facility (GEF) which is a special fund for adaptation, the Adaptation Fund, and ODA and concessional lending of which mush less than $1 \%$ is focused on adaptation (Stern 2006).

GEF resources include:

- Least Developed Country Fund (LDCF) caters for the immediate adaptation needs of least developed countries and supports the preparation of the National Adaptation Programmes of Action (NAPAs). Pledges and contributions to this fund amounted to $\$ 89$ million by 2006 . In 2007 commitments stood at only $\$ 163$ million and only $\$ 67$ million was actually delivered (Oxfam 2007).

- Special Climate Change Fund (SCCF) to address the special needs of developing countries in long-term adaptation, especially in the areas of health, agriculture, water and vulnerable ecosystems. By 2006 \$45 million had been pledged.

The Adaptation Fund will probably generate funding in the region of US $\$ 100-U S \$ 500$ million by 2012 when a 2\% levy on most Clean Development Mechanism (CDM) transactions in terms of the Kyoto Protocol comes into force (Stern 2006). The CDM gives developing countries an important source of carbon finance to assist in funding sustainable development projects. However, in 2007 only a small portion of emission reduction projects were located in Africa with only 30 out of a total 1600 projects worldwide being in Africa. But in April 2009, 23 African countries submitted a total of 102 projects. This is an encouraging trend since it puts African countries in a better position to get resources for adaptation (Africa Partnership Forum 2009).

These funds have, however, been heavily criticised for being both fiscally and technically inadequate. By March 2008 the total resources pledged to the various UNFCCC Funds amounted to only US $\$ 290$ million. Donors furthermore tend to delay on meeting their pledged commitments which means that the actual funds received were only US\$201.7 million (Ayers \& Huq 2008). 
Although the World Bank estimated in August 2010 that the cost of adaptation in developing countries may be between US\$70-100 billion per year, the contributions to dedicated adaptation funds are projected to be only between US\$150-US\$300 million per year (World Bank, 2010). Therefore, the World Bank recently had to recognise the essential role of the International Financial Institutions in funding adaptation to climate change (Stern 2006).

At the Financing for Development Conference on Climate Change during 2009, additional amounts were pledge that fall outside of the UNFCCC funding, as indicated in Table 2.

Table 2: Climate Change Funding Initiatives outside the UNFCCC

\begin{tabular}{|l|l|l|}
\hline FUND & $\begin{array}{l}\text { PLEDGED } \\
\text { AMOUNT }\end{array}$ & PLEDGOR \\
\hline $\begin{array}{l}\text { Climate Investment Fund (CIF) (includes Strategic } \\
\text { Climate Fund (SCF) and Clean Technology Fund } \\
(\mathrm{CTF})\end{array}$ & US $\$ 6.3$ billion & World Bank \\
\hline Forest Carbon Partnership Facility (FCPF) & US $\$ 165$ million & World Bank \\
\hline Carbon Partnership Facility (CPF) & US $\$ 470$ million & World Bank \\
\hline Congo Basin Forest Fund & US $\$ 200$ million & AFDB \\
\hline Strategic Priority on Adaptation (SPA) & US $\$ 50$ million & GEF \\
\hline UN-REDD Programme & US $\$ 35$ million & UNDP \\
\hline $\begin{array}{l}\text { MDG Achievement Fund - Environment and } \\
\text { Climate Change window (MDG) }\end{array}$ & US $\$ 90$ million & UNDP \\
\hline EU- Global Climate Change Alliance (GCCA) & US $\$ 30$ million & EU \\
\hline Cool Earth Initiative & US $\$ 10$ billion & Japan \\
\hline Environmental Transformation Fund & US $\$ 1.2$ billion & UK \\
\hline International Climate Initiative & US $\$ 170$ million & Germany \\
\hline International Forest Carbon Initiative & US $\$ 180$ million & Australia \\
\hline TOTAL & US $\$ 19.16$ billion & \\
\hline
\end{tabular}

Source: Africa Partnership Forum 2009.

\section{Conclusion}

Climate change may have irreparable effects on the development prospects of developing countries, Africa in particular. Africa suffers both from and adaptation deficit, as well as from a lack of sufficient human and financial capital to adapt to the looming crisis. It is evident that adaptation effects are already riddled with problems, such as reliable cost estimates, the honouring of pledges and the disbursement of funds. As long as developed countries and development agencies procrastinate on the issues, it is the developing countries that will feel the detriment of climate variability hardest.

An analysis of the various sources of adaptation funds, combined with the pledged ODA funding, indicates clearly that expected cost and expected funding do not match. Adaptation costs have been underestimated by at least 50 per cent and it means that separating adaptation funding from development funding will become even more complicated. The MDGs relating to poverty reduction, increased primary school enrolment, maternal health 
and environmental protection are all indirectly affected by the outcome of climate change and will likely see Africa sliding down the scale of development indicators.

The following policy changes are, therefore, recommended:

- Funding for adaptation in developing countries must be "sufficient and sustained" (UNFCCC 2007:6). An important aspect of funding is that despite the shortfalls, it is also very cumbersome and lengthy for developing countries to access these funds. It is crucial that funding for adaptation be both uninterrupted and adequate (UNFCCC 2007).

- The estimated costs of adaptation must be separated from the other costs required for development (UN 2010). The huge deficit in funding for adaptation in developing countries means that financing is a key issue in climate negotiations (Africa Partnership Forum 2009).

- In the Bali Action Plan (BAP) the possibility of obtaining new avenues of funding was suggested. New sources of finances from the international arena are needed to cater for climate change in Africa (Africa Partnership Forum 2009).

- Since a major part of funding resources is outside the UNFCCC framework, in the short term, it would be a challenge to bring it under the UNFCCC which is what developing countries want (Africa Partnership Forum 2009).

- Developed countries need to ensure that they provide sufficient funds/resources in line with the stipulations of the BAP. Ensure a just allocation of international adaptation funding so that the African countries stand to meet the challenges of climate change (Africa Partnership Forum 2009).

\section{Bibliography}

Adger, W., Arnell, N. \& Tompkins. E. 2005. "Successful Adaptation to Climate Change Across Scales." Global Environmental Change (15):88-86.

Africa Partnership Forum (AFP). 2009. Financial Resources and Investment for Climate Change. Special Session on Climate Change, 3 September 2009, Ethiopia.

African Union (AU) Commission, United Nations Economic and Social Council \& Economic Commission for Africa. 2010. Climate Change and Development in Africa. Meeting of the Committee of Exports of the $3^{\text {rd }}$ Joint Annual Meetings of the AU Conference of Ministers of Economy and Finance and ECA Conference of African Ministers of Finance, Planning and Economic Development, 25-28 March 2010, Malawi.

Agrawla, S. \& Fankhauser, S. 2008. Economic Aspects of Adaptation to Climate Change: Costs, Benefits and Policy Instruments. OECD. Paris. 
Ashton, P. J. 2002. “Avoiding Conflicts Over Africa's Water Resources.” Ambio 31(3):236242.

Ayers, J. \& Huq, S. 2008. "Supporting Adaptation to Climate Change: What Role for Official Development Assistance?” Annual Conference 2008: Development's Invisible Hands: Development Futures in a Changing Climate. 8 November 2008. International Institute for Environment and Development: London.

Boko, M., Niang, I., Nyong, A., Vogel, C., Githeko, A., Medany, M., Osman-Elasha, B., Tabo, R. \& Yanda, P. 2007. "Africa. Climate Change 2007: Impacts, Adaptation and Vulnerability." Contribution of Working Group II to the Fourth Assessment Report of the Intergovernmental Panel on Climate Change, Parry, M.L., Cnziani, O.F., Palutikof, J. P., van der Linden, P. J. \& Hanson, C.E. (eds). Cambridge University Press. Cambridge UK, 433-467.

BusinessGreen. 2009. “African Union to call for $\$ 67$ bn a year in climate funding." Http://www.BusinessGreen.com

Christensen, J.H., Hewitson, B., Busuioc, A., Chen, A., Gao, X., Held, I., Jones, R., Kolli, R.K., Kwon, W-T., Laprise, R., Magana Rueda, V., Mearns, L., Menendez, C.G., Raisanen, J., Rinke, A., Sarr, A. \& Whetton, P. 2007. "Regional Climate Projections." Climate Change 2007: The Physical Science Basis. Contribution of Working Group I to the Fourth Assessment Report of the Intergovernmental Panel on Climate Change. Soloman, S., Qin, D., Manning, M., Chen, Z., Marquis, M., Averyt, K.B., Tognor, M., \& Miller, H.L. (eds). Cambridge University Press. Cambridge.

De Wit. M. \& Jacek, S. 2006. "Changes in Surface Water Supply Across Africa with Predicted Climate Change.” Africa Earth Observatory Network (AEON), University of Cape Town. South Africa.

European Environment Agency (EEA). 2007. Climate change: the Cost of Inaction and the Cost of Adaptation. Technical Report no 13. EEA.

Few, R., Ahern, M., Matthies, F. \& Kovats, S. 2004. Floods, health and climate change: a strategic review. Working Paper No.63, Tyndall Centre for Climate Change Research.

Fischer, G., Mahendra, S. \& van Velthuizen, H. 2002. Climate Change and Agricultural Variability. A special report on Climate Change and Agricultural Vulnerability, Contribution to the World Summit on Sustainable Development. Johannesburg 2002.

Food and Agricultural Organization (FAO). 2003. World Agriculture: Towards 2015/2030An FAO Perspective. FAO. Rome.

Guernier, V., Hochberg, M., \& Guergan, J-F. 2004. "Ecology drives the worldwide distribution of human disease.” Plos Biology, 2(6):740-746.

Intergovernmental Panel on Climate Change (IPCC). 2007. Fourth Assessment Report: A Report of working Group I of the IPCC. http://www.ipcc.ch

McMichael, A.J., Campbell-Lendrum, D., Kovats, R.S., Edwards, S., Wilkinson, P., Edmonds, N., Nicholls, N., Hale, S., Tanser, F.C., Le Suefur, D., Schilesinger, M., Andronove, N.2004. "Climate Change in Comparative Quantification Health Risks: Global and Regional Burden of Disease due to Selected Major Risk Factors". Ezzati, 
M., Lopez, A.D. Rodgers, A. \& Murray, C.J. (eds). Ch 20:1543-1649. World Health Organization. Geneva.

Meehl, G.A., Stocker, T.F., Collins, W.D., Fredlingstein, P., Gaye, A.T., Gregory, J.M., Kitoh, A., Knutti, R., Murphy, J.M., Noda, A., Raper, S.C.B., Waterson, I.G., Weaver, A. J.\& Zhao, Z-C. 2007. "Global Climate Projections. In: Climate Change 2007: The Physical Science Basis." Contribution of the Working Group I to the Fourth Assessment Report of the Intergovernmental Panel on Climate Change. Solomon, S., Qin, D., Manning, M., Chen, Z., Marquis, M., Averyt, K.B., Tignor, M. \& Miller, H.L. (eds). Cambridge University Press. Cambridge.

Nicholls, R.J. 2004. Coastal flooding and wetland loss in the $21^{\text {st }}$ century: changes under the SRES climate and socio-economic scenarios. Global Environmental Change. 14:69-86.

Nkomo, J., Nyong, A. \& Kulindwa, K. 2006. "The Impacts of Climate Change in Africa”. Final Report submitted to the Stern Review on the Economics of Climate Change. http://www.hm-treasury.gov.uk...Chapter

Noy, I. 2009. The Macroeconomic Consequences of Disaster." Journal of Development Economics (88):221-231.

O’Brien, K. 2006. “The Economics of Adaptation”. Stern Review Workshop.http...

Oxfam International. 2007. "Briefing Note 4 December 2007: Financing Adaptation . Why the UN's Bali Climate Conference must mandate the search for new funds." http://www.oxfam.org

2010. "Briefing note 31 May 2010: Climate Finance Post-Copenhagen. The S100 bn questions.” http://www.oxfam.org

Parry, M., Arnell, N., Berry, P., Dodman, D., Frankhauser, S. \& Hope, C. 2009. Assessing the Costs of Adaptation to Climate Change: A Review of the UNFCCC and Other Recent Estimates. International Institute for Environment and Development and Grantham Institute for Climate Change: London.

Sheppard, C.R.C. 2003. Predicted recurrences of mass coral mortality in the Indian Ocean. Nature. 425:294-297.

Stanton, E. \& Ackerman, F. 2009. "Climate and Development Economics: Balancing Science, Politics and Equity”. Natural Resources Forum 33:262-273.

Stern, N. 2006. The Stern Review on the Economic Effects of Climate Change. CUP: Cambridge.

United Nations Development Program (UNDP). 2004. Adaptation to Climate Change: Doing Development Differently. UNDP. http://www.undp.org

2006. Human Development Report 2006. Beyond Scarcity: Power, Poverty and the Global Water Crisis. UNDP. http://www.undp.org/hrd2006/report.cfm

United Nations Economic Commission for Africa (UNECA). 2010. Economic Report on Africa 2010. Promoting high-level sustainable growth to reduce unemployment in Africa. www.uneca, org

United Nations Environmental Programme (UNEP). 2007.Global outlook for ice and snow. 
http://www.unep.org/geo/geo_ice/>

United Nations Framework Convention on Climate Change (UNFCCC). 2007. Climate Change: Impacts, Vulnerability and Adaptation in Developing Countries. UN Office. Geneva. http://unfccc.int/resource/docs/2007/sbi/eng/02.pdf

World Bank. 2010. The Economics of Adaptation to Climate Change. A Synthesis Report. World Bank: Washington.

World Health Organization (WHO) 2004. The World Health Report 2003 - Shaping the Future. WHO. Geneva. http://www.who.int 